\title{
Basic Data Report For Monitor Well AEC-7 (C-2742) Reconfiguration Activities
}

(Waste Isolation Pilot Plant)

January 2005

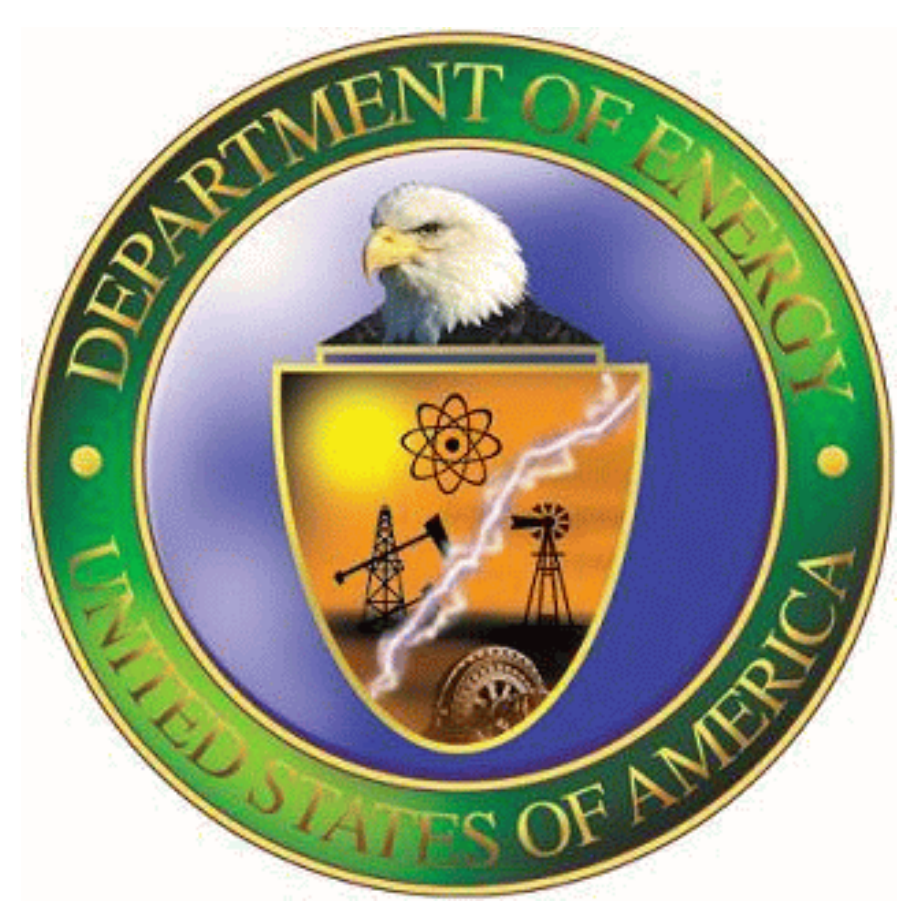


This document has been submitted as required to:

Office of Scientific and Technical Information

P.O. Box 62

Oak Ridge, TN 37831

(615) 576-8401

Additional information about this document may be obtained by calling (800) 336-9477. Copies may be obtained by contacting the National Technical Information Service, U.S. Department of Commerce, 5285 Port Royal Road, Springfield, VA 22101.

Processing and final preparation of this report was performed by the Waste Isolation Pilot Plant Management and Operating Contractor for the U.S. Department of Energy under Contract No. DE-AC04-01AL66444. 


\author{
Basic Data Report \\ For Monitor Well AEC-7 (C-2742) \\ (Waste Isolation Pilot Plant)
}

\author{
Richard A. Salness \\ Washington Regulatory and Environmental Services \\ P.O. Box 2078 \\ Carlsbad, NM 88220
}

January 2005 


\section{Basic Data Report for Monitor Well AEC-7 Reconfiguration Activities}

DOE/WIPP-04-3308

\section{TABLE OF CONTENTS}

ABBREVIATIONS AND ACRONYMS $\ldots \ldots \ldots \ldots \ldots \ldots \ldots \ldots \ldots$ ii

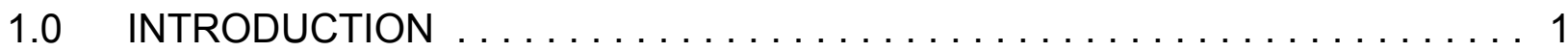

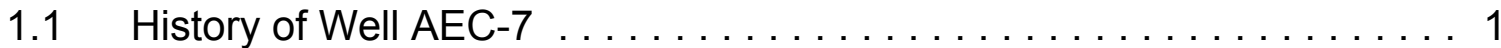

1.2 Regulatory Requirements for Reconfiguration of AEC-7 . . . . . . . 2

1.2.1 New Mexico Statutes .......................... 5

1.2.2 New Mexico OSE Rules and Regulations ............. 5

1.2.3 State of New Mexico Energy, Minerals, and Natural

Resources Department Oil Conservation Commission

(Order No. R-111-P) . . . . . . . . . . . . . . . . 6

2.0 WELL RECONFIGURATION ...................... 6

$2.1 \quad$ Removal of Packers and Tubing $\ldots \ldots \ldots \ldots \ldots \ldots \ldots \ldots$

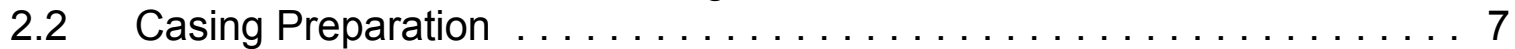

$2.3 \quad$ Drilling of Borehole $\ldots \ldots \ldots \ldots \ldots \ldots \ldots \ldots \ldots \ldots \ldots$

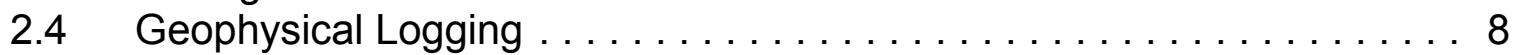

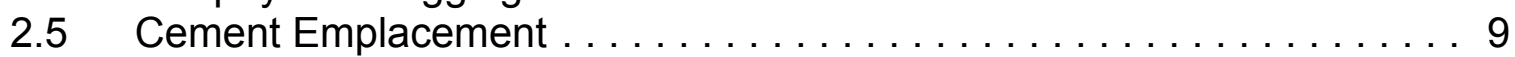

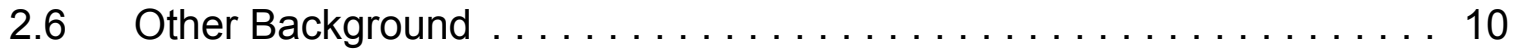

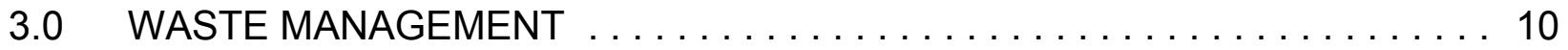

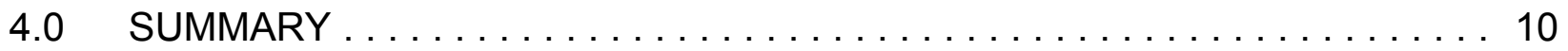

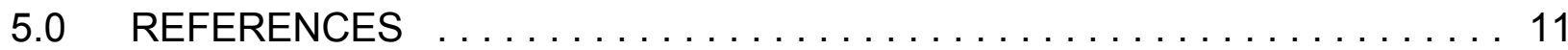

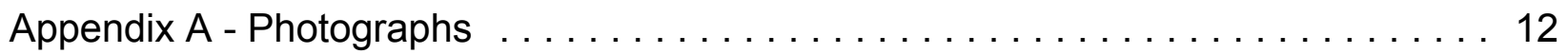

Appendix B - Field Report by Haliburton Energy Services Field Representative

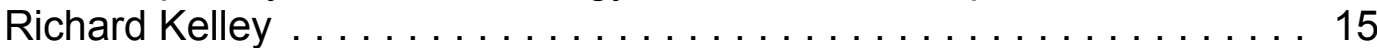

\section{LIST OF FIGURES}

Figure $1-1$ - Location Map $\ldots \ldots \ldots \ldots \ldots \ldots \ldots \ldots \ldots \ldots \ldots \ldots \ldots \ldots \ldots \ldots \ldots$

Figure 1-2 - Construction of Well AEC-7 Before Reconfiguration $\ldots \ldots \ldots \ldots \ldots 4$

Figure 2-1 - Construction of Well AEC-7 After Reconfiguration $2004 \ldots \ldots \ldots \ldots$. . . 9 


\section{ABBREVIATIONS AND ACRONYMS}

$\begin{array}{ll}\begin{array}{ll}\text { bgs } \\ \text { BLM }\end{array} & \begin{array}{l}\text { below ground surface } \\ \text { U.S. Bureau of Land Management }\end{array} \\ \text { DOE } & \text { U.S. Department of Energy } \\ \text { EPA } & \text { U.S. Environmental Protection Agency } \\ \text { ERDA } & \text { U.S. Energy Research and Development Administration } \\ \text { NMED } & \text { New Mexico Environment Department } \\ \text { NMSA } & \text { New Mexico Statutes Annotated } \\ \text { OSE } & \text { Office of State Engineer (New Mexico) } \\ \text { P\&A } & \text { plugging and abandonment } \\ \text { ROW } & \text { right-of-way } \\ \text { SNL } & \text { Sandia National Laboratories } \\ \text { TCLP } & \text { Toxicity Characteristic Leaching Procedure } \\ \text { TK-70 } & \text { Tube-Kote 70 } \\ \text { WIPP } & \text { Waste Isolation Pilot Plant }\end{array}$




\subsection{INTRODUCTION}

The Waste Isolation Pilot Plant (WIPP) is a U.S. Department of Energy (DOE) facility disposing of transuranic and mixed waste under the Hazardous Waste Facility Permit (Permit NM4890139088-TSDF, as amended) issued by the New Mexico Environment Department (NMED). WIPP is located approximately 26 miles east of Carlsbad, New Mexico, in eastern Eddy County (Figure 1-1). Disposal panels are being excavated in the Permian Salado Formation at a depth of approximately 2,150 feet (ft) below ground surface (bgs).

Over the years a number of groundwater monitor wells have been installed for site characterization and to monitor temporal and spatial changes in groundwater elevation and chemistry at WIPP. Many of the wells used for this purpose were constructed of carbon steel casing that has deteriorated to varying degrees due to corrosion. For some wells, the deterioration has led to failure of the well integrity. In such cases, the well must either be reconfigured or completely plugged, according to regulatory requirements, to prevent commingling of groundwater from different formations. Other wells are nearing the end of their useful life and/or are duplicative of other wells that serve the same purpose. Because of these integrity issues, WIPP has begun a program to plug and abandon wells that are no longer useful for the monitoring program or are redundant, and to reconfigure other wells for future monitoring. One such well is known as AEC-7, which was reconfigured to monitor only the Culebra Member of the Rustler Formation.

The New Mexico Office of the State Engineer (OSE) permitted well AEC-7 as C-2742. This well has been part of the far-field monitoring network since 1974. The well was used to obtain water level elevations and hydraulic parameters from both the Bell Canyon Formation and the Culebra Member of the Rustler Formation. This basic data report provides a historical account of the well from the original installation to the current configuration.

\subsection{History of Well AEC-7}

AEC-7 (OSE File \# C-2742) is approximately 3.5 miles northeast of the WIPP Site Boundary in Section 31, Township 21 south, Range 31 east (Figure 1-1). AEC-7 was drilled in 1974 by Oak Ridge National Laboratory for the U.S. Energy Research and Development Administration (ERDA) to evaluate the stratigraphy of the geological units for development of WIPP.

AEC-7 was reported to be cased through the Rustler Formation with 8.625-inch casing to a depth of 1004 feet bgs (SAND89-7056). However, during geophysical analysis in April 2004, the caliper logging indicated the casing was set at 1,006 feet bgs (Figure 1-2). Well AEC-7 was originally drilled to a total depth of 3,906 feet bgs in the Anhydrite II of the Castile Formation. The well was cased to a depth of 1,006 feet bgs in the upper Salado Formation, leaving open hole to total depth. Sandia National Laboratories (SNL) deepened AEC-7 to 4720 feet bgs in 1979 to investigate hydraulic properties of the Bell Canyon Formation. AEC-7 was then plugged from 4,483 feet bgs 


\section{Basic Data Report for Monitor Well AEC-7 Reconfiguration Activities}

DOE/WIPP-04-3308

to 4453 feet bgs to seal the pressure and up borehole flow from the Bell Canyon Formation from the remainder of the hole. The well was capped and remained unused until 1988. AEC-7 was reentered in 1988 by SNL to reconfigure the well as a Culebra monitor well. The well was configured with a retrievable bridge plug (open-hole packer) at approximately 950 feet bgs. An additional packer was installed at a depth of 841 feet bgs to isolate the Culebra Member for hydraulic testing (Figure 1-2).

WIPP has retained the Right-of-Way (ROW) reservation lease with the U.S. Bureau of Land Management (BLM) since August 30, 2002 (ROW \#NM-108365). The ROW contains special stipulations regarding maintenance, reconfiguration, and plugging and abandonment (P\&A). One of the stipulations required any monitoring well which penetrated the salt section be cased. AEC-7 was completed as an open hole through the salt section. Therefore, based on this stipulation, the BLM required WIPP to reconfigure this well or plug and abandon it to prevent salt section exposure to groundwater.

During March and April of 2004 this well was reentered to reconfigure it to a Culebra monitoring well. The purpose of this reconfiguration was twofold. First, when the well was drilled, the completion was not compliant with OSE and Bureau of Land Management in that water bearing formations were possibly commingling and the Salado Formation was not sealed off with well casing. Second, Culebra Member water levels in this well were suspect, possibly due to improper sealing of the bridge plug and packer. Therefore it was determined to remove these packers and complete the well in one horizon.

\subsection{Regulatory Requirements for Reconfiguration of AEC-7}

Prior to initiating the P\&A/reconfiguration program, the applicable regulations regarding the subject were analyzed. The following regulations were reviewed for this analysis:

- New Mexico Statutes Annotated 1978, Section 72-14 regarding drilling, casing, repairing, and abandonment of artesian wells.

- $\quad$ New Mexico Office of The State Engineer Rules and Regulations regarding application filing for well drilling, repair, and P\&A.

- $\quad$ State of New Mexico Energy, Minerals, and Natural Resources Department Oil Conservation Commission (Order No. R-111-P) regarding the protection of mineral resources from commingling or leaking water sources.

- $\quad$ U.S. Bureau of Land Management (BLM) Stipulations for Right-of-Ways (ROWs) NM107944 and NM108365. 


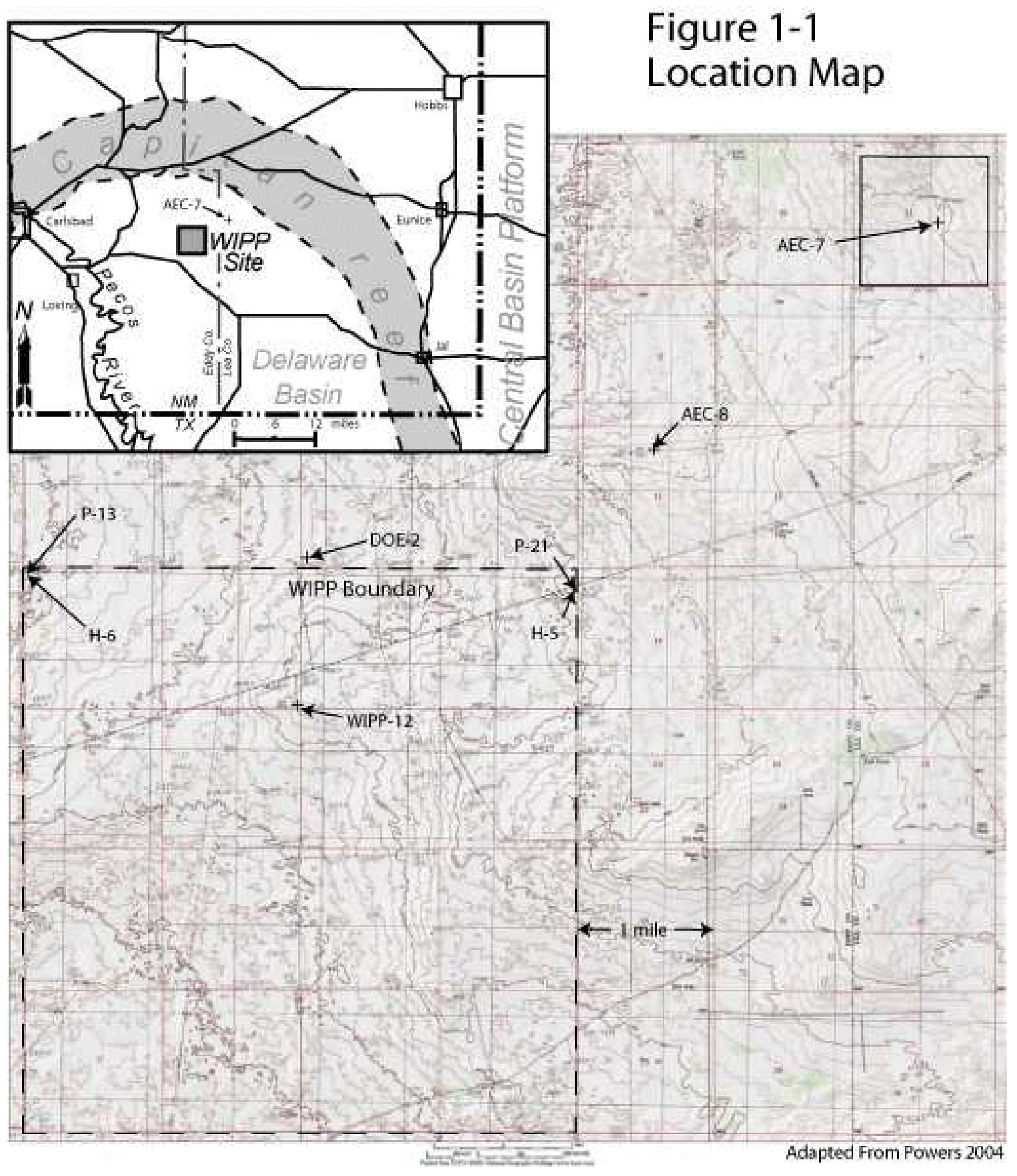




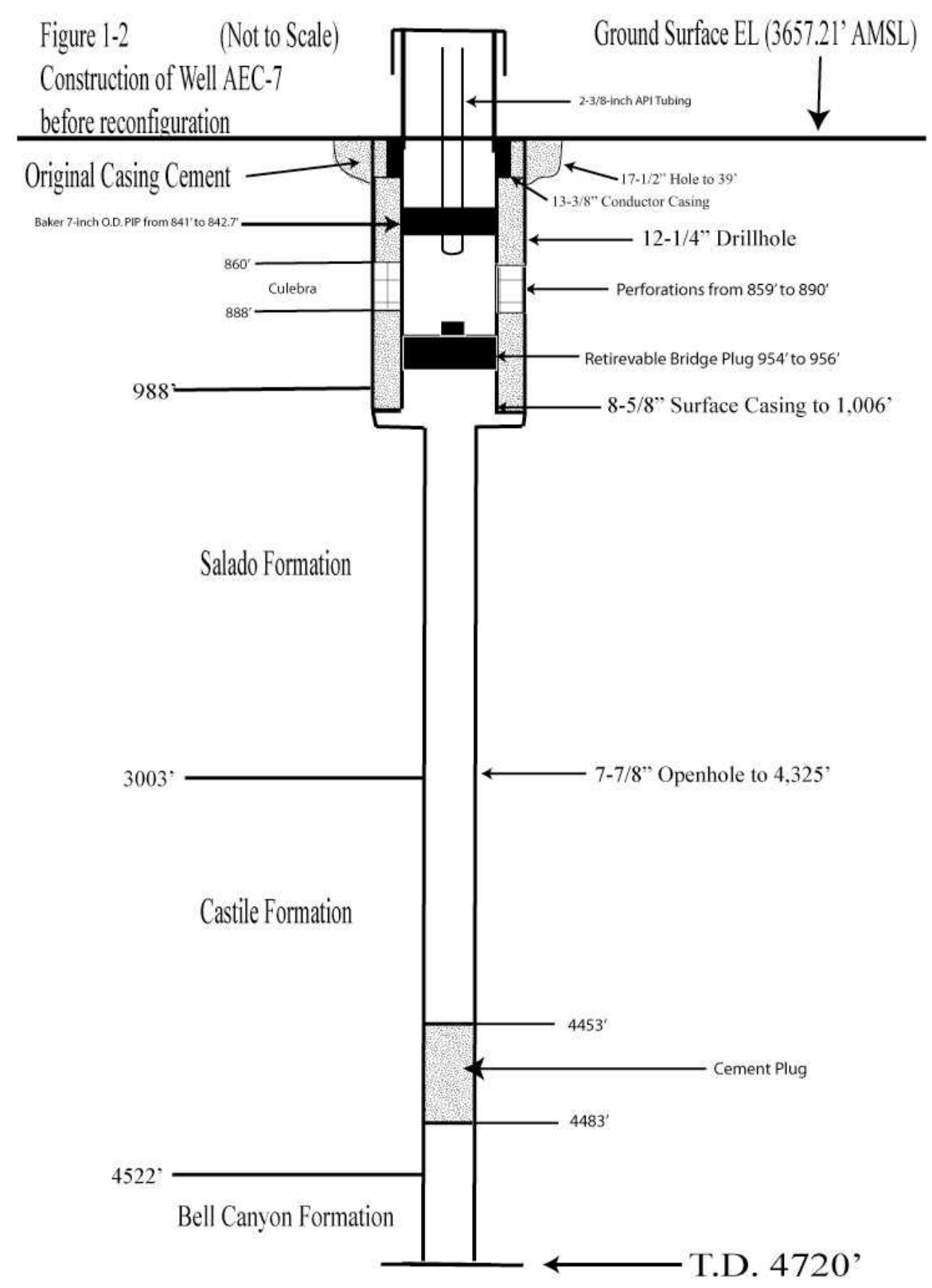

In the following sections there are terms used which are unique to the geology of southeastern New Mexico.

- $\quad$ "Potash Area" is defined in Oil Conservation Commission Order No. R-111-P. This represents the area of which potash mining operations are now in progress, or in which core tests indicate commercial potash reserves. This area is coterminous with the Known Potash Leasing Area as determined by the BLM. AEC-7 is located in this area and is subject to these regulations. 
- $\quad$ "Salt section" refers to the Salado Formation in which the McNutt Potash unit is deposited. Figure 1-2 graphically depicts the depth of the Salado Formation.

The applicable portions of the listed regulations are described in the following sections.

\subsubsection{New Mexico Statutes}

Section 72-13-4 of the New Mexico Statutes Annotated (NMSA) prescribes the rules and regulations governing the drilling, casing, repairing, and abandonment of artesian wells. This section authorizes the State Engineer to "prescribe and enforce reasonable rules and regulations consistent with terms of this act." Additionally, this section states that application to the State Engineer is required to drill, repair, plug or abandon an artesian well. All wells completed in the Magenta and Culebra Members of the Rustler Formation are considered artesian.

\subsubsection{New Mexico Office of the State Engineer Rules and Regulations}

Article 1-1 Filing

This Article defines the necessary action for filing an application to drill, repair, plug or abandon wells in the State of New Mexico. Prior to repair/reconfiguration activities the OSE must be notified through the application process of WIPP's intent to repair/reconfigure the monitor wells at the site.

\section{Article 4-16 Casing-Cementing-Testing}

This Article describes the cementing and cement testing approval requirements for emplacing cement plugs in wells and boreholes. This is the only regulation that prescribes types of cement, mixture ratios, and additive requirements. It is primarily for casing cementation during well installation, but is also acceptable for plugging.

This article specifies pump and plug methodology. The primary specification in this Article is the use of Class $C$ neat cement at a density of fifteen pounds per gallon.

This Article also specifies that cementing/P\&A programs shall be witnessed and approved by an authorized representative of the State Engineer.

\section{Article 4-19 Artesian Wells - Repair}

This article provides specifications that are most applicable to the P\&A program. Prior to commencement of repairs (i.e., reconfiguration), a representative of the State Engineer must inspect the well to "determine if the condition of the well is such that it may be repaired." Additionally, "the hole shall be open to allow the entrance of equipment for well logging and leakage measurement," which implies a degree of well integrity testing (e.g., cement bond log, ultrasonic imaging log). 
Article 4-19.1 Plugging

This section prescribes that "All work shall be done under the supervision of the State Engineer or his representative, or a representative of the appropriate Artesian Conservancy District who shall designate the amount of cement to be used and the depths at which cement plugs shall be set."

\section{Article 4-20 Test or Exploratory Wells}

Article 4-20 contains the rules for test or exploratory wells, which all the WIPP monitoring wells qualify. However, for P\&A (Article 4-20.2) of these wells the regulations defer to the artesian specifications contained in Article 4-19. Additionally, this section further states "Such wells shall be plugged in accordance with Article 4-19.1 so that fluids will be permanently confined to the specific strata in which they were originally encountered," thus preventing the commingling of water bearing zones.

\subsubsection{State of New Mexico Energy, Minerals, and Natural Resources Department Oil Conservation Commission (Order No. R-111-P)}

These regulations are designed to protect mineral resources from commingling or leaking water sources. The primary concern here is the Potash Area and protection of the salt section and any water bearing horizon. The regulations state:

1. "All wells heretofore and hereafter drilled within the Potash Area shall be plugged in a manner and in accordance with the general rules or field rules established by the Division that will provide a solid cement plug through the salt section and any water-bearing horizon and prevent liquids or gasses from entering the hole above or below the salt section."

2. "The fluid used to mix the cement shall be saturated with the salts common to the salt section penetrated and with suitable proportions but not more than three (3) percent of calcium chloride by weight of cement being considered the desired mixture possible." This regulation was discussed with the OCC and BLM regarding applicability to cementing for reconfiguration. It was determined through this discussion that it applied to drilling of wells and not the reconfiguration application for this program.

\subsection{WELL RECONFIGURATION}

Well AEC-7 was reconfigured during March and April 2004 to monitor only the Culebra Member of the Rustler Formation. The purpose of this reconfiguration was twofold. First, when the well was drilled, the completion was not compliant with OSE and Bureau of Land Management in that water bearing formations were possibly commingling and the Salado Formation was not sealed off with the well casing and cement. Second, water-level data for the Culebra Member in this well were suspect, possibly due to a failed packer. 
Figure 1-2 shows the configuration of well AEC-7, as built prior to this reconfiguration. The new configuration for AEC-7 was planned to monitor only the Culebra. To do this the existing packers and tubing needed to be removed from the borehole, the casing needed to be prepared for geophysical logging, and the well cemented from the cement plug to the bottom of the surface casing. The following sections describe the reconfiguration process for AEC-7.

\subsection{Removal of Packers and Tubing}

Removal of the packer took place during the period of March 19-22, 2004. Typical removal of packers and tubing involves connecting the drill rig elevator to the existing tubing and applying enough pressure to break the shear pin and drain the packer fluid, thus relieving the pressure, then pulling the remaining packer mandrel assembly and element from the hole. For this well there was an open-hole packer and tubing set above the Culebra perforations and an open-hole packer, used as a bridge plug, set below the Culebra perforations (Figure 1-2).

On March 19, 2004, the drill rig latched onto the tubing attached to the upper open-hole packer in an attempt to shear the pin and remove it from the borehole. The pressure was relieved; however, after removing approximately ten feet of tubing, the tubing broke. After inspecting the broken piece that was removed it was apparent that corrosion in combination of debris on top of the packer was the cause of the weakened tensile strength of the pipe, at a depth of approximately twenty feet from the surface. After the pipe broke, the packer and remaining tubing string fell down the hole to the approximate depth of the bridge plug at 950 feet.

With the remaining tubing and packer at depth, the workover crews setup an overshot fishing tool to retrieve the equipment from the hole. Circulation was set up to remove loosened debris as the overshot tool was lowered into the hole. The tubing and packer were successfully removed from the hole on March 21, 2004, using the overshot tool. The well was circulated to remove excess debris sitting on top of the bridge plug before reentering the borehole for retrieval.

Retrieval of the bridge plug was first attempted using a J-hook tool. Several attempts were made using the J-tool without success. It was not initially apparent why the J-tool was not able to grab the bridge plug for retrieval. After trying the J-tool a decision was made to remove the plug with the overshot tool used to remove the plug/open-hole packer. After one attempt the bridge plug was removed from the hole on March 22, 2004 , and it became very apparent why the J-tool could not latch onto the plug. The extensions that the J-tool connects to were sheared from the packer assembly, preventing a solid connection.

\subsection{Casing Preparation}

Casing preparation and circulation took place on March 23 and 24, 2004. Following the removal of the packers, the casing was scraped to remove debris and significant pitting from the casing surface in preparation for geophysical logging (Appendix A). The 


\section{Basic Data Report for Monitor Well AEC-7 Reconfiguration Activities}

DOE/WIPP-04-3308

casing was scraped from the top to the bottom until resistance was no longer evident on the scraping tool. After scraping, the debris was circulated from the borehole to the surface storage tank. While circulating the borehole the tremie pipe hit obstructions at 1,095 feet bgs, 1,263 feet bgs, and 1,490 feet bgs. The tremie pipe washed out the first two obstructions (1,095 and 1,263 feet bgs); however, the obstruction at 1,490 feet bgs was too competent for the tremie pipe to breakthrough. At this point it was decided to obtain drill pipe at the site and ream out the hole while circulating out the debris with drilling fluids.

\subsection{Drilling of Borehole}

Drilling the borehole took place during the period of March 30 through April 1, 2004. Tremie pipe was removed and drill pipe, configured with a 7-7/8 inch drill bit, was used to ream out the hole utilizing drilling fluid to mobilize debris. To do this a portable mud pit, cuttings shaker, and drilling mud system was mobilized to the well pad. Drilling mud was employed to lift the heavy metallic casing debris and formation material from the borehole. Drilling mud consisted of salt clay and starch mixed with brine to a viscosity sufficient to lift materials from the hole (Appendix B).

Drill pipe, 3.5-inch diameter, configured with a 7-7/8-inch tri-cone rotary drill bit, was tripped into the borehole until refusal at 1,490 feet bgs. Drilling progressed nicely once passing through the obstruction at 1,490 feet bgs. Drilling stopped upon tagging the cement plug at 4,453 feet bgs (Figure 2-1). It was determined that the plug was competent after applying pressure from the drill rig.

\subsection{Geophysical Logging}

Following the removal of the packers, casing scraping, and drilling the borehole, the well was ready for geophysical logging on April 2, 2004. Halliburton Energy Services performed the logging. The types of geophysical logs performed were a 4-Arm Caliper Log, Cement Bond Log, and a Casing Inspection Log.

The 4-Arm Caliper Log was performed to provide information regarding the open-hole section of the borehole, and by inference, the degree of halite dissolution and/or creep in the borehole, and other formation stability. The greatest apparent diameter from the borehole center was 25 inches at a depth of 1,008 to 1,014 feet bgs in the Salado Formation just beneath the surface casing. An increase in apparent borehole diameter of 25 inches from center also was recorded in the Halite I of the Castile Formation at a depth of 4,153 feet bgs.

The Cement Bond Log was performed to evaluate the integrity of the cement bond with the casing and with the adjacent formation to assure there is no ability for interstitial commingling of groundwater between water bearing zones (i.e., Magenta and Culebra Members). The bond log was run from 93 feet bgs to a depth of 1,003 feet bgs.

According to interpretations made by the Halliburton Field Representative, Richard Kelley, the cement bond is excellent with no indications of channeling. There is bonding to both the pipe and formation (Appendix B). 


\section{Basic Data Report for Monitor Well AEC-7 Reconfiguration Activities DOE/WIPP-04-3308}

The Casing Inspection Log was performed to measure the wall thickness of the casing to determine if detrimental corrosion has occurred since installation that would require corrective action prior to full well reconfiguration. According to the Halliburton Field Representative, Richard Kelley, the quality of the pipe is overall very good (Appendix B). Copies of all logs are contained in the project files at the WIPP site.

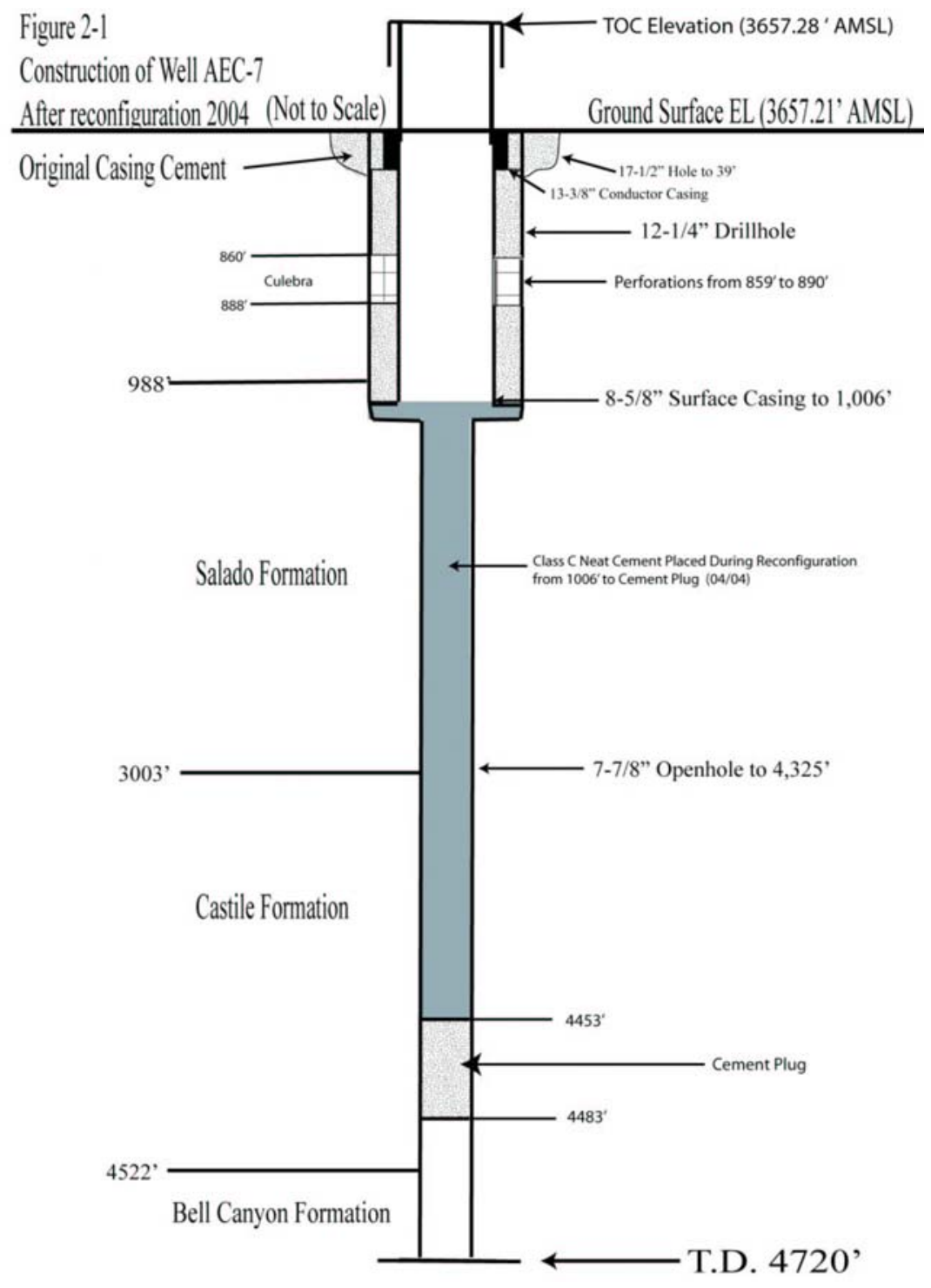

\subsection{Cement Emplacement}

After geophysical logging the site was prepared to emplace cement into the hole utilizing a tremie pipe. Tremie pipe was placed into the hole to a depth of 4,160 feet bgs. Class $C$ neat cement was prepared at the Lafarge materials plant in Carlsbad, New Mexico, and trucked to the well pad for emplacement. Cement from the 


\section{Basic Data Report for Monitor Well AEC-7 Reconfiguration Activities}

DOE/WIPP-04-3308

trucks was poured into a tub at ground surface and pumped by tremie pipe into the borehole in lifts. Because the borehole had a competent cement plug from 4,453 to 4,483 feet bgs, there was not a concern to emplace a smaller cement plug for the first batch of cement. A total of 1,094 cubic feet of cement were used to complete the configuration as presented in Figure 2-1. Cement was emplaced in the well over the course of four days (April 5-8, 2004) and four lifts. Lifts consisted of 648, 230, 189, and 27 cubic feet of cement, respectively. The last load of cement was hand mixed at the pad to top off the cement column placed days earlier and bring the cement level up to the bottom of the casing $(1,006$ feet bgs).

\subsection{Other Background}

Well workover services were performed by Stewart Brothers Drilling Company, 306 Airport Road, Milan, New Mexico, under contract with Washington TRU Solutions LLC (WTS). Their New Mexico Water Well Driller License number is WD-331. Fishing tool services and packers were provided by Weatherford, $2117 \mathrm{~N}$. French Drive, Hobbs, New Mexico 88241. Geophysical logging was conducted by Halliburton Energy Services, 2311 First Street, Artesia, New Mexico 88210. Mike Stapleton of the New Mexico Office of the State Engineer was notified of cement emplacement; however, he did not witness the activity.

\subsection{WASTE MANAGEMENT}

During drilling activities and emplacement of cement during plugging activities the brine water in the borehole was displaced to the surface. The water was captured from the wellhead casing through a right-angle discharge pipe at the surface, then into a trough. A transfer pump moved the water from the trough into a 500 barrel storage tank prior to disposal. Debris removed from the well was separated and placed into a 55 gallon drum prior to disposal.

The captured water and debris was characterized for disposal by analysis using Toxicity Characteristic Leaching Procedure (TCLP). The TCLP analyses were performed for Resource Conservation and Recovery Act metals. All analyses indicated the brine water was nonhazardous. Following receipt of the analytical results the brine water collected at AEC-7 was disposed in the lined $\mathrm{H}-19$ evaporation pond. A total of 500 barrels were disposed in the $\mathrm{H}-19$ evaporation pond. A full 55-gallon drum of well debris was disposed of at Lea Land. Analytical reports and disposal records are retained on site in the site compliance records. These records may be obtained upon request.

\subsection{SUMMARY}

AEC-7 (OSE File \# C-2742) is located approximately 3.5 miles northeast of the WIPP Site Boundary in Section 31, Township 21 south, Range 31 east (Figure 1-1). AEC-7 was drilled in 1974 by Oak Ridge National Laboratory for the ERDA to evaluate the stratigraphy of the geological units for development of WIPP. AEC-7 was originally drilled and cased through the Rustler Formation, then drilled to the base of the 
Anhydrite II unit in the Castile Formation. Before casing well AEC-7, hydraulic tests were performed on selected test intervals above the Salado Formation, including the Culebra Member of the Rustler Formation. In 1979, AEC-7 was deepened by SNL into the Bell Canyon Formation for a series of hydraulic tests on the Bell Canyon. AEC-7 was reentered in 1988 by SNL and perforated across the Culebra Member interval to allow well development, hydraulic testing, and water level monitoring (SAND89-7056).

During March and April of 2004 this well was reentered to reconfigure it to a Culebra monitoring well. The purpose of this reconfiguration was twofold. First, when the well was drilled, the completion was not compliant with the OSE and BLM in that water bearing formations were possibly commingling and the Salado Formation was not sealed off with well casing. Second, Culebra Member water levels in this well were suspect, possibly due to improper sealing of the bridge plug and packer. Therefore it was determined to remove these packers and complete the well in the Culebra.

\subsection{REFERENCES}

Stensrud, W. A., M. A. Bame, K. D. Lantz, J. B. Palmer, and G. J. Saulnier, Jr. 1990. WIPP Hydrology Program Waste Isolation Pilot Plant, Southeastern New Mexico, Hydrologic Data Report \#8. SAND89-7056, Sandia National Laboratories, Albuquerque, NM 
Appendix A

Photographs 


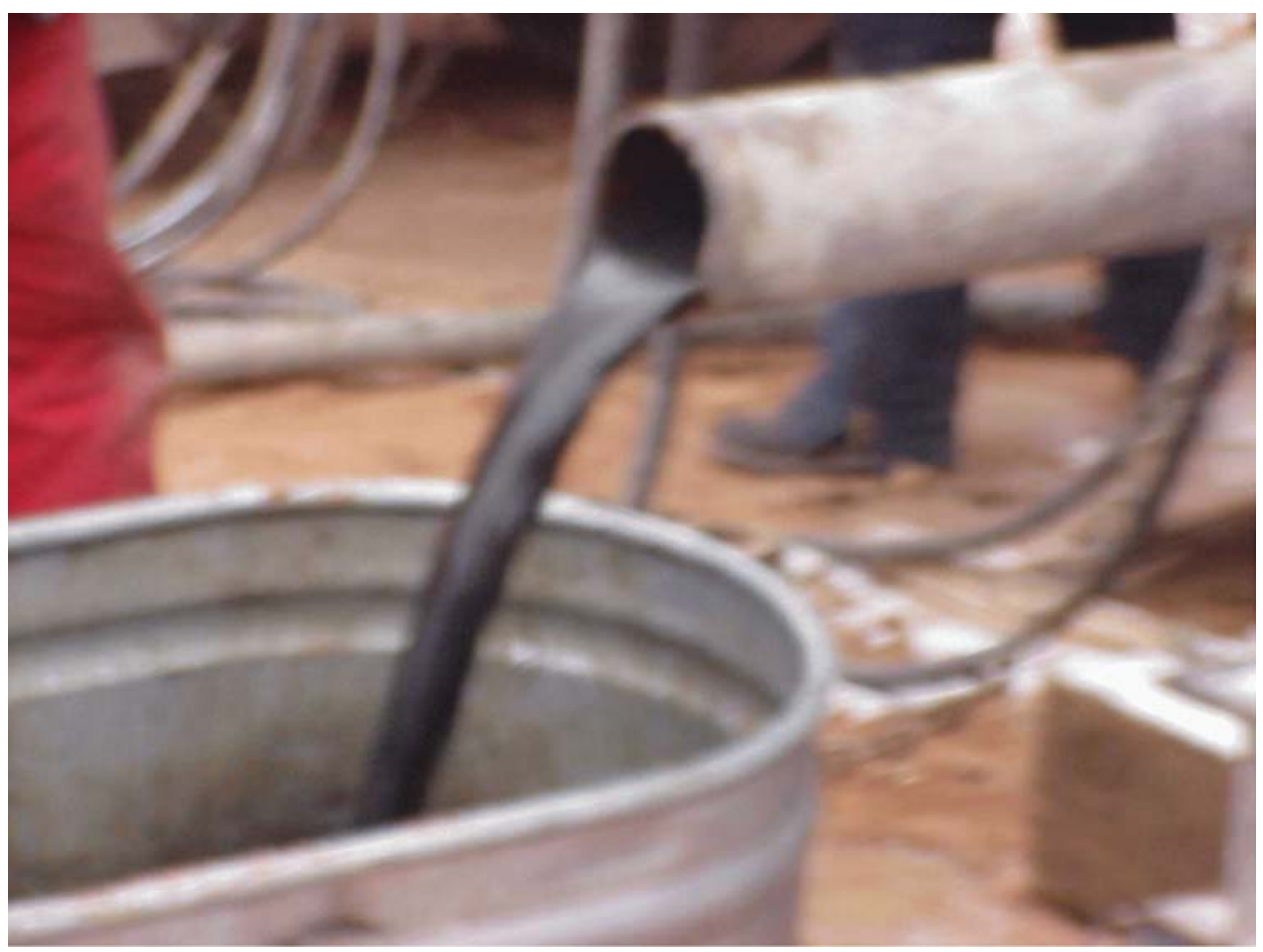

Typical Debris Circulated Out of AEC-7 
Basic Data Report for Monitor Well AEC-7 Reconfiguration Activities DOE/WIPP-04-3308

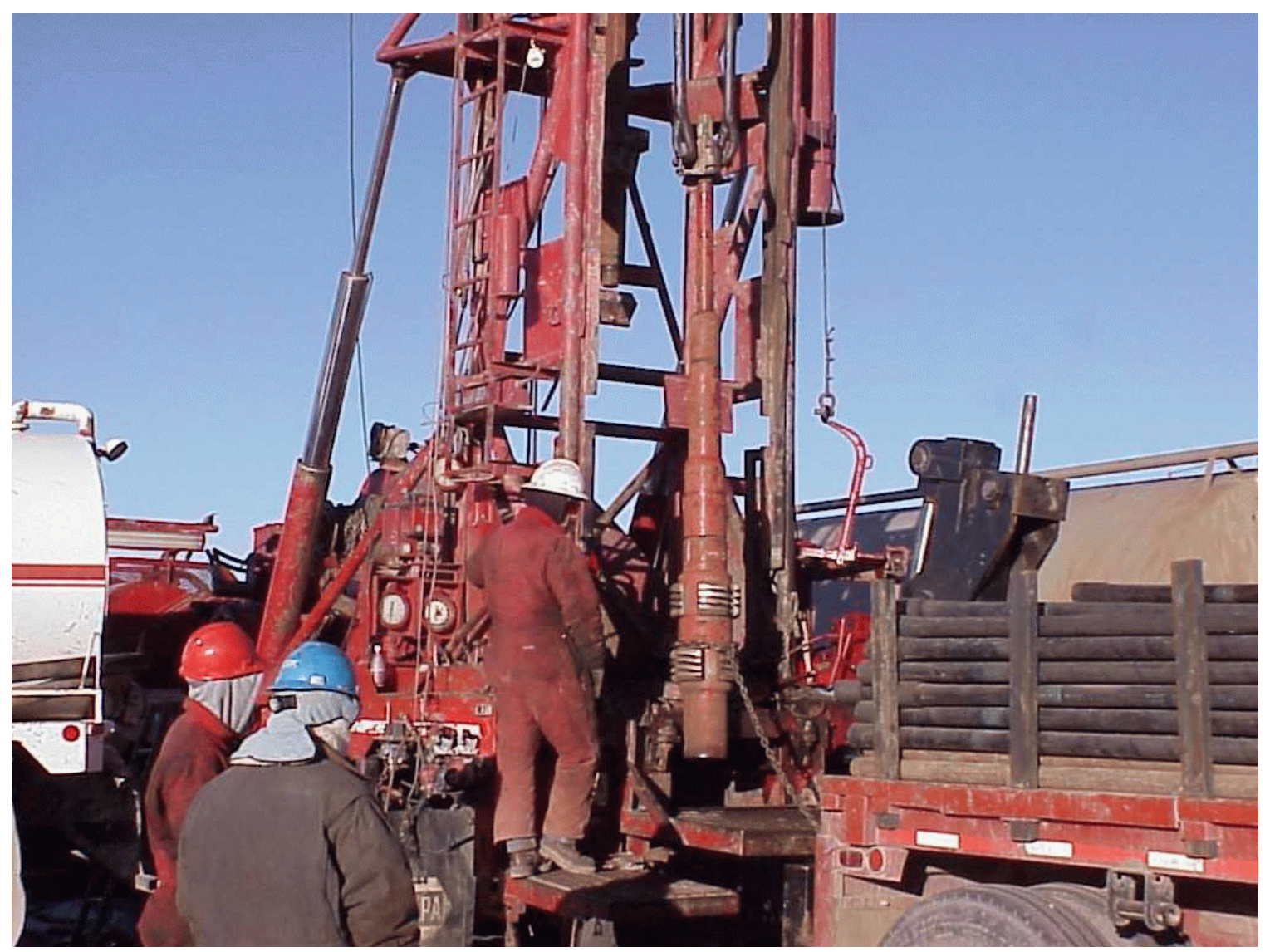

Casing Scraper Used at AEC-7 


\section{Appendix B \\ Field Report by Haliburton Energy Services \\ Field Representative Richard Kelley}




\section{Basic Data Report for Monitor Well AEC-7 Reconfiguration Activities}

DOE/WIPP-04-3308

\section{Log Analysis of the AEC-7 Well}

The cement bond quality is excellent with no indications of channeling. There is bonding to both the pipe and the formation.

The quality of the pipe is overall very good.

The caliper log is self explanatory. It shows the total volume.

The Tools

The cement bond tool is the conventional low frequency acoustic bond tool. This tool can only be used for the overall quality of the cement. It will indicate channels but will not output a map of the channels.

The casing inspection tool used was a high frequency acoustic tool (CAST-V). This tool arrives at the thickness by the frequencies returning to the receivers. It obtains the internal diameter from the travel time of the sonic signal. This tool is only designed for an overall quality of the pipe. It is unlikely to determine small holes since it is not taking readings on $100 \%$ of the pipe.

The caliper tool is a four armed caliper tool which takes reading from the $X-Y$ axis. The volumes are then calculated from these readings.

Should there be any questions regarding this, I can be reached at 505-914-0324.

Richard Kelley

Field Sales Representative

Halliburton Energy Services 